\title{
Methionine Transport in Salmonella typhimurium: Evidence for at Least One Low-affinity Transport System
}

\author{
By P. D. AYLING, ${ }^{1}$ T. MOJICA-A ${ }^{2 *}$ AND T. KLOPOTOWSKI ${ }^{2}$ \\ 1 Unit of Genetics, Department of Plant Biology, University of Hull, Hull, HU6 7RX \\ ${ }^{2}$ Institute of Biochemistry and Biophysics, Polish Academy of Sciences, \\ Rakowiecka 36, Warsaw, Poland
}

(Received 1 February 1979)

\begin{abstract}
The systems which transport methionine in Salmonella typhimurium LT2 have been studied. Fourteen mutants, isolated by three different selection procedures, had similar growth characteristics and defects in the specific transport process showing a $K_{\mathrm{m}}$ of $0.3 \mu \mathrm{M}$ for L-methionine, and therefore lack the high-affinity, metP transport system. The sites of mutation in four of the mutants were shown by P1-mediated transduction to be linked $(0.3$ to $1.1 \%$ ) with a proline marker located at unit 7 on the $S$. typhimurium chromosome. The high-affinity system was subject to both repression and transinhibition by methionine, and it may also be regulated by the met $J$ and met $K$ genes. There appeared to be at least two additional transport systems with relatively low affinities for methionine in the metP763 mutant strain, with apparent $K_{\mathrm{m}}$ values for methionine of $24 \mu \mathrm{M}$ and approximately $1.8 \mathrm{mM}$. The latter system, with a very low affinity for methionine, was inhibited by leucine. In addition, methionine inhibited leucine transport, suggesting that one of the low-affinity methionine transport systems may actually be a leucine transport system.
\end{abstract}

\section{INTRODUCTION}

Amino acids and other small molecules are transported into the bacterial cell by a large number of transport systems. Some are specific and have high affinities for their substrates; others have broader specificities and low affinities. This presents a complication in the genetic analysis of transport systems, since in many cases a single compound is transported by two or more systems, and it is therefore difficult to isolate mutants lacking only one system because the other system or systems may be sufficiently active to compensate for the missing activity.

A high-affinity transport system for L-methionine has been described in Salmonella typhimurium (Ayling \& Bridgeland, 1972) and Escherichia coli (Kadner, 1974; Kadner \& Watson, 1974). Mutants lacking the activity of this system are designated metP in $S$. typhimurium and metD in $E$. coli. The system has an apparent $K_{\mathrm{m}}$ for methionine of about $0 \cdot 1 \mu \mathrm{M}$ in both species and shows a high degree of specificity. None of the other common amino acids inhibits its activity with L-methionine as substrate, although D-methionine and certain methionine analogues are weak inhibitors.

MetP mutants in $S$. typhimurium were isolated as resistant to either of two growth inhibitory analogues, $\alpha$-methylmethionine or methionine sulphoximine (Ayling \& Bridgeland, 1972). Later studies showed that those methionine sulphoximine-resistant mutants which were defective in methionine transport were also defective in glutamine transport.

* Present address: College of Medicine and Dentistry of New Jersey, New Jersey School of Osteopathic Medicine, Piscataway, New Jersey 08854, U.S.A. 
In fact, these strains were double mutants, possessing, in addition to the met $P$ mutation, a mutation in $g \ln P$, the gene specifying a component of the high-affinity glutamine transport system (Betteridge \& Ayling, 1975). Both the met $P$ and the $g \ln P$ mutations were necessary for full resistance to methionine sulphoximine.

Ayling \& Bridgeland (1972) discussed three lines of evidence which suggested the presence of at least one additional methionine transport system in S. typhimurium. Firstly, an analysis of the kinetics of methionine transport in a wild-type strain revealed two components. Secondly, analogue-resistant mutants defective in the met $P$ system still transported a significant amount of methionine. Thirdly, metP transport mutations did not restrict the ability of methionine auxotrophs to grow at maximum rate on low concentrations of Lmethionine. Mutants in a second, low-affinity, component of transport have been isolated in E. coli (Kadner \& Watson, 1974).

The present work describes additional properties of the mutants in the high-affinity system, and presents evidence that there is one, possibly two, transport systems in addition to the metP system. Some of these results have been presented in a preliminary communication (Ayling, 1977).

\section{METHODS}

Media. Nutrient agar (NA), nutrient broth (NB) and minimal medium (MM) were as described by Ayling \& Bridgeland (1972). Minimal agar (MA) was MM solidified with 1.5\% (w/v) Davis Standard Agar. MM and MA were supplemented where required with amino acids $\left(20 \mu \mathrm{g} \mathrm{ml}^{-1}\right.$ with respect to the $\mathrm{L}$-isomer) or vitamin $B_{12}\left(0 \cdot 1 \mu \mathrm{g} \mathrm{ml}^{-1}\right)$. Lennox agar (LA) and Lennox broth (LB) were those of Lennox (1955).

Chemicals. L- $\left[\right.$ methyl $\left.-{ }^{14} \mathrm{C}\right]$ Methionine $\left(51 \cdot 2\right.$ or $\left.56 \mu \mathrm{Ci} \mu \mathrm{mol}^{-1}\right)$, DL- $\left[1-{ }^{14} \mathrm{C}\right]$ methionine $\left(62 \mu \mathrm{Ci} \mu \mathrm{mol}^{-1}\right)$, L[U- ${ }^{3}$ H]leucine $\left(209 \mu \mathrm{Ci} \mu \mathrm{mol}^{-1}\right)$ and L- $\left[\right.$ methylene- $\left.{ }^{14} \mathrm{C}\right]$ tryptophan $\left(52 \mu \mathrm{Ci} \mu \mathrm{mol}^{-1}\right)$ were obtained from The Radiochemical Centre, Amersham. D-[1- $\left.{ }^{14} \mathrm{C}\right]$ Methionine $\left(62 \mu \mathrm{Ci} \mu \mathrm{mol}^{-1}\right)$ was prepared by growing strain metE205 dadA52 (HU106) with $10 \mu \mathrm{M}$ DL- $\left[{ }^{14} \mathrm{C}\right]$ methionine as a methionine source. The dadA mutation prevents this strain from converting $\mathrm{D}$-methionine to $\alpha$-ketomethiolbutyric acid, the first of the two steps in the production of L-methionine from D-methionine (Wild et al., 1974). Therefore this strain utilizes only the L- $\left[{ }^{14} \mathrm{C}\right]$ methionine and leaves most of the ${ }^{\mathrm{D}}-\left[{ }^{14} \mathrm{C}\right]$ methionine in the medium. Once growth had ceased, the bacteria were sedimented and the supernatant was sterilized by filtration. The maximum amount of $\mathrm{L}-\left[{ }^{14} \mathrm{C}\right]-$ methionine remaining in the preparation was $<5 \%$, as determined by incubating samples with L-amino acid oxidase plus catalase (both from Sigma) and measuring the production of $\alpha$-keto $\left[{ }^{14} \mathrm{C}\right]$ methiolbutyric acid.

ICR 191 B was kindly donated by Dr H. J. Creech; ethyl methanesulphonate (EMS) was obtained from Sigma; $N$-methyl- $N^{\prime}$-nitro- $N$-nitrosoguanidine (NG) was obtained from Koch-Light. Methionine and related compounds were from the following sources: L- and D-methionine, glycyl-DL-methionine, $\alpha$-keto- $\gamma$-methiolbutyric acid, L-methionine amide hydrochloride, L-methionine-DL-sulphoximine, $S$-methyl-L-cysteine, $\alpha$ methyl-DL-methionine, DL-norleucine and seleno-DL-methionine, all from Sigma; DL-ethionine, from Kodak; $N$-acetyl-L-methionine and L-methionine methyl ester hydrochloride, from Fluorochem, Glossop, Derbyshire. Other amino acids were from B.D.H., Sigma and Koch-Light. Chloramphenicol (Chloromycetin) was the gift of Parke, Davis \& Co., Pontypool, Gwent. The scintillation fluid contained $6 \mathrm{~g}$ 2,5-diphenyloxazole and $0.4 \mathrm{~g}$ 1,4-di-[2-(5-phenyloxazolyl)]benzene (both from Koch-Light) in 11 xylene.

Bacteria and phage. The bacterial strains were all derived from Salmonella typhimurium LT2, and their origin or mode of construction is described in Table 1 and below.

Phage P22 int -4 (Smith \& Levine, 1967) and P22 HT int-4, isolated by G. Roberts, and kindly supplied by Dr G. F. Ames, were used for transductions. Phage P1CMclr-103 carrying the CM chloramphenicol resistance marker (Kondo \& Mitsuhashi, 1964) and a temperature-sensitive repressor (Rosner, 1972) was used for transduction with P1-sensitive derivatives of $S$. typhimurium. Phage Felix O, kindly supplied by Dr E.S. Anderson, was used to isolate rough, $\mathrm{gal}^{-}$strains which are P1-sensitive.

Genetic methods. Transduction with phage P22 and conjugation were as described by Ayling \& Chater (1968). Phage preparations (titres about $10^{10}$ phage $\mathrm{ml}^{-1}$ ) were made by infecting bacteria with $10^{6}$ to $1 \mathrm{C}^{7}$ phage in soft NA layers.

Recombinants, $\mathrm{Pro}^{+} \mathrm{His}^{+}$, from the conjugation cross HfrA metP760 hisD23 (HU77) $\times$proA46 leu-1003 purC7 ilv-405 (HU93) were selected on MA+adenine + isoleucine+leucine, and purified by single colony isolation on the same medium. The inheritance of the leu-1003 allele was determined by replication, and the inheritance of metP760 was determined by the radial streak method (see below). 
Table 1. Salmonella typhimurium metP mutants and other strains used

\begin{tabular}{|c|c|}
\hline HU no. & Strain* \\
\hline 103 & LT2 (wild-type) \\
\hline 36 & metE205 ara-9 \\
\hline 163 & metE205 metP760 \\
\hline 84 & metE205 metP761 glnP251 \\
\hline 151 & metE205 metP762 glnP253 \\
\hline 181 & metE205 metP763 ara-9 \\
\hline 182 & metE205 metP764 ara-9\} \\
\hline 108 & metE205 metP765 ara-9 \\
\hline 109 & metE205 metP766 ara-9\} \\
\hline 262 & metE205 metP767 glnP252 \\
\hline 253 & metE205 metP1707 ara-9 \\
\hline 349 & metE205 metP1708 glnP256 ara-9 \\
\hline 350 & metE205 metP1709 glnP257 ara-9 \\
\hline 412 & metE205 metP1710 glnP258 ara-9 \\
\hline 413 & metE205 metP1711 glnP259 ara-9 \\
\hline 414 & metE205 metP1712 glnP260 ara-9. \\
\hline 107 & metE205 dadA51 ara-9! \\
\hline 106 & metE205 dadA52 ara-9\} \\
\hline 411 & metE205 ${ }^{+}$dadA52 ara-9 \\
\hline 98 & HfrK4 ser A13 \\
\hline 77 & HfrA metP760 hisD23 galK50 \\
\hline 100 & $\begin{array}{l}\text { HfrA metP762 glnP253 hisD23 } \\
\text { galK50 }\end{array}$ \\
\hline 21 & HfrA hisD23 galK50 \\
\hline 93 & $\begin{array}{l}\text { proA46 leu-1003 purC7 ilv-405 } \\
\text { rha str-r }\end{array}$ \\
\hline 290 & metE205 metP760 galE $\ddagger$ \\
\hline 293 & $\begin{array}{l}\text { pro-624 hisD } 2421 \text { ilvC } 401 \\
\text { metE338 ara-9 galE str-r }\end{array}$ \\
\hline 284 & metE205 ${ }^{+}$metP760 \\
\hline 285 & met E205 metP760 $\}$ \\
\hline 322 & $\begin{array}{l}\text { met } E 205^{+} \text {met } P 760^{+} \\
\text {(i.e. wild-type) }\end{array}$ \\
\hline 323 & metE205 ${ }^{+}$metP763 \\
\hline 33 & metB23 \\
\hline 62 & metB23 metJ744 \\
\hline 410 & met $B 23^{+}$metJ744 \\
\hline 409 & metB23 $3^{+}$metJ $\left.744^{\div}\right\}$ \\
\hline 65 & met $K 721$ \\
\hline 375 & met $K 725$ \\
\hline 7 & $\arg F 111 \operatorname{ser} A 13$ \\
\hline 394 & $\operatorname{argF111}$ metK721 \\
\hline 395 & $\left.\operatorname{argF111} \operatorname{metK} 721^{+}\right\}$ \\
\hline 399 & $\operatorname{met} B 23^{+}$met $K 721^{+}$ \\
\hline 398 & met $B 23^{+}$metK721 \\
\hline 397 & $\operatorname{met} B 23 \operatorname{met} K 721^{+}$ \\
\hline 396 & met $B 23$ met $K 721$ \\
\hline 405 & metB23 $3^{+}$metK $725^{+}$ \\
\hline 404 & met $B 23^{+}$metK725 \\
\hline 403 & metB23 metK $725^{+}$ \\
\hline 402 & met $B 23$ met $K 725$ \\
\hline
\end{tabular}

Source or reference $\dagger$

\author{
G. F. Ames \\ D. A. Smith \\ Betteridge \& Ayling (1975) \\ Betteridge \& Ayling (1975) \\ HU36 $\times$ HU100, conjugation \\ From HU36, ICR mutagenesis, resistant to AM, \\ unable to grow on D-methionine \\ From HU36, NG mutagenesis, unable to grow \\ on D-methionine. A. F. Rogers \\ Betteridge \& Ayling (1975) \\ From HU36, spontaneous, resistant to AM, \\ unable to grow on D-methionine
}

From HU36, spontaneous, resistant to METX, unable to grow on D-methionine

From HU36, NG mutagenesis, unable to grow on D-methionine. A. F. Rogers

HU106 $\times$ HU103, transduction

C. Colson

Ayling \& Bridgeland (1972)

From HU21, ICR mutagenesis, resistant to METX

K. E. Sanderson

C. Colson

From HU163, resistant to Felix O phage galE derivative from TR302, from J. R. Roth

HU163 $\times$ HU103, transduction

HU285 $\times$ HU103, transduction

HU181 $\times$ HU103, transduction

D. A. Smith

Ayling \& Chater (1968)

HU62 $\times$ HU103, transduction
A. C. Hobson
A. C. Hobson
D. A. Smith
HU7 $\times$ HU65, transduction
HU395 $\times$ HU33, transduction
HU394 $\times$ HU33, transduction
HU395 $\times$ HU33, transduction
HU394 $\times$ HU33, transduction

As HU396 to HU399, except derived from HU375

* Symbols as in Sanderson \& Hartman (1978).

$\dagger$ In conjugation and transduction crosses, the recipient is given first and the donor second. Abbreviations: AM, $\alpha$-methylmethionine; METX, methionine sulphoximine; NG, $N$-methyl- $N^{\prime}$-nitro- $N$-nitrosoguanidine. $\ddagger$ P1-sensitive galE derivatives of other metE metP strains described in Results were isolated in the same way. 
The methods for transduction of $S$. typhimurium with phage P1CMclr-100 have been described by Ornellas \& Stocker (1974), Enomoto \& Stocker (1974) and Mojica-a (1975). In general, P1-sensitive derivatives of S. typhimurium were isolated from mutants resistant to Felix O phage. P1CMclr-100 lysates were prepared either by induction of $\mathrm{P} 1$ lysogens at $40^{\circ} \mathrm{C}$ (since the clr-100 mutation makes the phage repressor unstable at this temperature), or by infection of P1-sensitive strains with phage in soft LA at $30^{\circ} \mathrm{C}$. P1 phage was assayed using Shigella dysenteriae strain 16 (kindly supplied by Dr J. R. Guest) as an indicator.

The isolation of metP760 and metP761 (Ayling \& Bridgeland, 1972) and metP767 (Betteridge \& Ayling, $1975)$ have already been described. The new metP mutants were isolated in three different ways:

(1) for resistance to $\alpha$-methylmethionine: $0.1 \mathrm{ml}$ of an overnight NB culture of metE205 (HU36) was spread on $\mathrm{MA}+\mathrm{B}_{12}+\alpha$-methylmethionine $\left(1 \mathrm{mg} \mathrm{ml}^{-1}\right)$. After $48 \mathrm{~h}$ incubation at $37^{\circ} \mathrm{C}$, resistant colonies were picked and streaked twice on NA. [MetP763, metP764 and metP1707; the first two mutants were isolated after ICR mutagenesis (Roth, 1970).]

(2) for resistance to methionine sulphoximine: selection as in (1) except that mutants were selected from metE205 on MA $+\mathrm{B}_{12}+$ analogue $\left(50 \mu \mathrm{g} \mathrm{ml}^{-1}\right)$. [MetP1708, metP1709, metP1710, metP1711 and metP1712. MetP762 was similarly isolated from HfrA hisD23 (HU21).]

(3) for failure to grow on D-methionine: metE205 was mutagenized with NG (Ayling \& Chater, 1968) and mutants were isolated which failed to grow on MA+D-methionine at $10 \mu \mathrm{g} \mathrm{ml}^{-1}$, but which grew on MA+ L-methionine at $20 \mu \mathrm{g} \mathrm{ml}^{-1}$. (MetP765, metP766.)

Reversion tests on the metE metP strains were performed by spreading $0.1 \mathrm{ml}$ samples of overnight NB cultures on to MA+D-methionine $\left(10 \mu \mathrm{g} \mathrm{ml}^{-1}\right)$. Either one crystal of NG, one drop (approx. $0.03 \mathrm{ml}$ ) of EMS or one drop of a solution of ICR $191 \mathrm{~B}\left(1 \mathrm{mg} \mathrm{ml}^{-1}\right)$ was placed on the agar surface. The appearance of a ring of more than 100 revertants around the mutagen was scored as strong reversion; about 10 to 20 revertants were scored as weak reversion.

Growth responses of metE metP strains. The responses of these strains to various methionine sources were tested by placing paper discs containing $80 \mu \mathrm{g}$ of the compound (about $0.5 \mu \mathrm{mol}$ ) in the centre of MA plates which had been overlaid with soft MA layers containing $0 \cdot 1 \mathrm{ml}$ samples of overnight NB cultures resuspended in $0.85 \%(\mathrm{w} / \mathrm{v})$ saline. Responses of the same strains to the analogues $\alpha$-methylmethionine (AM) and methionine sulphoximine (METX) were tested by the radial streak method (Ames \& Roth, 1968). Discs containing $2 \mathrm{mg} \mathrm{AM}$ or $200 \mu \mathrm{g}$ METX were placed in the centre of an MA $+\mathrm{B}_{12}$ plate. Overnight NB cultures were resuspended in saline and streaked radially from the edge of the disc to the outside of the plate.

Methionine uptake. The method normally used was as described by Ayling \& Bridgeland (1972). Exponentially growing cultures (usually $75 \mathrm{ml}$ at an $A_{650}$ of 0.6 to 0.8 , determined in a Unicam SP600 spectrophotometer) were incubated with chloramphenicol $\left(200 \mu \mathrm{g} \mathrm{ml}^{-1}\right)$ for $30 \mathrm{~min}$, washed once and resuspended in $\mathrm{MM}+$ chloramphenicol (chloramphenicol medium, CM). Suspensions were adjusted to 1 to $2 \mathrm{mg}$ dry wt $\mathrm{ml}^{-1}$ (using a dry weight calibration curve in which an $A_{650}$ of 1.0 corresponded to $395 \mu \mathrm{g}$ dry wt ml-1). All operations subsequent to the chloramphenicol treatment were performed at room temperature $\left(20\right.$ to $\left.23{ }^{\circ} \mathrm{C}\right)$.

Transport activity was stable for at least $1 \mathrm{~h}$ in bacterial suspensions prepared this way, and assays were normally performed within this time. The final volume of the assay mixture was 0.5 to $2.0 \mathrm{ml}$ except where noted otherwise. The assay temperature was $25^{\circ} \mathrm{C}$, and the final concentration of bacteria ranged from 50 to $400 \mu \mathrm{g}$ dry wt ml-1. The rate of reaction was proportional to the concentration of bacteria up to at least $400 \mu \mathrm{g}$ per filter. The reaction was initiated by mixing bacteria and labelled amino acid (plus additions, where specified) in a $15 \times 120 \mathrm{~mm}$ test tube. Samples $(0.2 \mathrm{ml}$ or $1.0 \mathrm{ml})$ were removed with an automatic pipette and placed on membrane filters ( $25 \mathrm{~mm}$ diam., $0.45 \mu \mathrm{m}$ pore size, Millipore or Oxoid) and washed with $5 \mathrm{ml} \mathrm{CM}$ at room temperature. In some experiments the total reaction mixture was poured on to the filter. The filters were dried and placed in $5 \mathrm{ml}$ scintillation fluid. Radioactivity was determined in a Reckman LS200 or Packard Tricarb scintillation counter.

In a preliminary screaning of the metE metP strains for possible transport defects a simplified version of the above procedure was used. Bacteria were grown overnight in $10 \mathrm{ml} \mathrm{MM}+$ glucose $(0.04 \%, \mathrm{w} / \mathrm{v})+\mathrm{B}_{12}(0 \cdot 1 \mu \mathrm{g}$ $\left.\mathrm{ml}^{-1}\right) ; 0.4 \%(\mathrm{w} / \mathrm{v})$ glucose was then added, and incubation was continued for $1.25 \mathrm{~h}$. The cultures were washed with $10 \mathrm{ml} \mathrm{CM}$ and resuspended in $2 \mathrm{ml} \mathrm{CM}$. The transport assays were then performed as described above, with a bacterial consentration of $100 \mu \mathrm{g} \mathrm{ml}^{-1}$ (assays with L- $\left[{ }^{14} \mathrm{C}\right]$ methionine or L- $\left[{ }^{14} \mathrm{C}\right]$ glutamine) or $200 \mu \mathrm{g} \mathrm{ml}^{-1}$ (assays with $\mathrm{D}-\left[{ }^{14} \mathrm{C}\right]$ methionine) in a $0.5 \mathrm{ml}$ assay mixture.

All uptake values are expressed as nmol (mg dry wt) $)^{-1}$, and are usually the averages of duplicate determinations. Results using radioactive amino acid concentrations greater than $1 \mu \mathrm{M}$ have been corrected for uptake by bacteria treated with toluene $(1 \%, v / v)$ for $2 \mathrm{~min}$. 
RESULTS

\section{Isolation and characterization of mutants altered in the high-affinity transport system}

Mutations in the high-affinity methionine transport system (1) confer resistance to AM at $1 \mathrm{mg} \mathrm{ml}^{-1}$, (2) confer resistance to METX at $50 \mu \mathrm{g} \mathrm{ml}^{-1}$ in strains which in addition carry the $g \ln P$ marker and (3) prevent growth of methionine auxotrophs on D-methionine at $10 \mu \mathrm{g} \mathrm{ml}^{-1}$. MetP mutants isolated using each of these properties are described in Table 1 and in Methods. For example, following frameshift mutagenesis by ICR $191 \mathrm{~B}$ of the metE205 auxotrophic strain, two out of 332 AM-resistant mutants obtained from the mutagen-treated culture were unable to grow on D-methionine (metE205 metP763 and metE205 metP764).

The ability of ICR $191 \mathrm{~B}, \mathrm{NG}$ and EMS to revert the metE metP strains listed in Table 1 on D-methionine $\left(10 \mu \mathrm{g} \mathrm{ml}^{-1}\right)$ was tested. Met205 metP760 and metE205 metP1707 were strongly reverted by either NG or EMS; metE205 metP763 was strongly reverted and metE205 metP764 was weakly reverted by ICR $191 \mathrm{~B}$. None of the other metE metP strains was significantly reverted by these mutagens. It therefore appears that metP763 is a frameshift mutant (Oeschger \& Hartman, 1970), although genetic data to be presented later do not entirely support this conclusion.

The metE metP strains were also tested for their responses to various sources of methionine known to support growth of methionine auxotrophs (L- and D-methionine, $\mathrm{N}$-acetylmethionine and $\alpha$-ketomethiolbutyric acid). Paper discs containing each of these compounds were placed in the centre of plates seeded with soft MA layers containing the bacteria. The metE205 parent strain responded well to each of the four methionine sources. The metE $m e t P$ strains grew well on L-methionine. With the exception of metE metP1711 and metE $m e t P 1712$, all the $m e t P$ strains showed very little or no response to D-methionine at $80 \mu \mathrm{g}$ per disc, but showed some response to $800 \mu \mathrm{g}$ per disc; metE metP1711 and metE metP1712 showed a rather variable response to $80 \mu \mathrm{g}$. None of the nine strains tested (metP760 to metP1707, inclusive, Table 1) grew well on $N$-acetylmethionine, but all 14 grew well on $\alpha$-ketomethiolbutyric acid. This indicates that the metP+ $P^{+}$system is not involved in, or at least not exclusively involved in, the transport of $\alpha$-ketomethiolbutyric acid. Interestingly, the metE205 dadA5I and metE205 dadA52 strains (HU107 and HU106, respectively), which cannot grow on D-methionine because they are defective in the first of the two steps in the conversion of D- to L-methionine (Wild et al., 1974), failed to respond to the increased amount of D-methionine.

The metE205 metP strains were tested for their resistance to the analogues AM and METX using the radial streak method (Ames \& Roth, 1968). All of the strains were resistant to $\mathrm{AM}$, whereas only those strains which also contained $g \ln P$ mutations in the high-affinity glutamine transport system (metP761, metP762, metP767, metP1708, metP1709, metP1710, metP1711 and metP1712) were resistant to METX. The two metE dadA strains were fully sensitive to both analogues.

In a preliminary survey of possible transport defects, all of the 14 met $E$ metP strains in Table 1, and the met $E$ parent strain, were grown in $M M+\mathrm{B}_{12}$ and tested by a rapid method

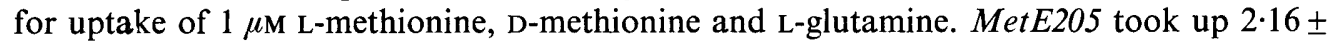
$0.15 \mathrm{nmol} \mathrm{L}$-methionine $\min ^{-1}\left(\mathrm{mg}\right.$ dry wt) ${ }^{-1}, 0.49 \pm 0.09 \mathrm{nmol} \mathrm{D}$-methionine and $1.28 \pm$ $0.38 \mathrm{nmol}$ L-glutamine (average of four determinations, each in duplicate). All of the metP mutants except metP1709 were extremely defective in the uptake of L-methionine, taking up $<4 \%$ of the wild-type amount; metPI709 took up $21 \%$ of the wild-type amount and is presumed to be a leaky metP mutant. All of the mutants, including metP1709, showed less than $5 \%$ of the wild-type uptake of D-methionine. The mutants fell into two classes with respect to glutamine uptake; the metP760, metP763, metP764, metP765, metP766 and $m e t P 1707$ strains (which were all sensitive to METX) were similar to the metE strain (55 to 


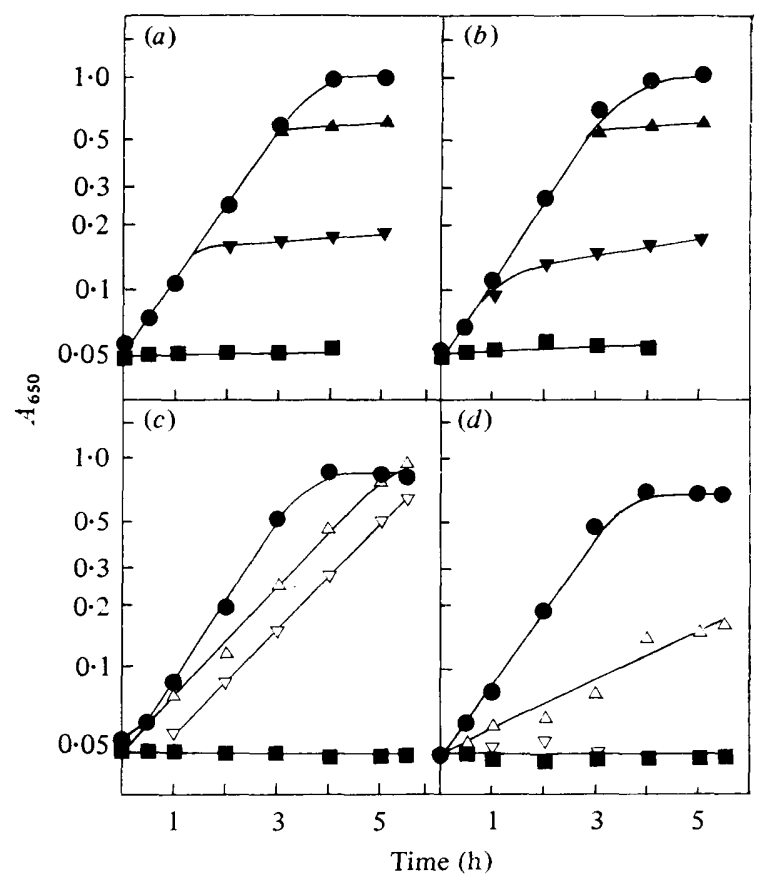

Fig. 1. Growth of metE205 (HU36) $(a, c)$ and metE205 metP763 (HU181) $(b, d)$ in minimal medium containing $\mathrm{L}$ - or D-methionine. No additions $(\square) ; \mathrm{L}$-methionine at $1 \mu \mathrm{g} \mathrm{ml}^{-1}(\boldsymbol{\nabla})$, $5 \mu \mathrm{g} \mathrm{ml}^{-1}(\Delta)$ or $10 \mu \mathrm{g} \mathrm{ml}^{-1}(\bigcirc)$; D-methionine at $10 \mu \mathrm{g} \mathrm{ml}^{-1}(\nabla)$ or $100 \mu \mathrm{g} \mathrm{ml}^{-1}(\Delta)$.

$170 \%$ of the wild-type level), whereas the metP761, metP762, metP767, metP1708, metP1709, metP1710, metP1711 and metP1712 strains (which were all resistant to METX) showed 2 to $16 \%$ of the wild-type uptake. The latter strains showing the reduced glutamine uptake are presumed to carry a mutation in the $g \ln P$ gene, although the $g \ln P$ mutations have only been located approximately by conjugation for the metP761 and metP767 strains.

The responses of metE205 and metE205 metP763 to various concentrations of L- and D-methionine were further measured in liquid media (Fig. 1). The metP763 mutation had little effect on the growth rate or final growth yield of the metE205 auxotroph in concentrations of L-methionine as low as $1.0 \mu \mathrm{g} \mathrm{ml}^{-1}$, i.e. $6.7 \mu \mathrm{M}$ (Fig. $1 a, b$ ). MetE205 grew more slowly on D-methionine at 10 or $100 \mu \mathrm{g} \mathrm{ml}^{-1}$ than on L-methionine (Fig. $1 \mathrm{c}$ ). The failure of metE205 metP763 to grow on D-methionine at $10 \mu \mathrm{g} \mathrm{ml}^{-1}$, i.e. $67 \mu \mathrm{M}$, indicated that only the metP system transports sufficient of the compound at this concentration (Fig. $1 d$ ). In confirmation of the plate tests, metE205 metP763 did respond slowly to a higher concentration of D-methionine $\left(100 \mu \mathrm{g} \mathrm{ml}^{-1}\right)$. The simplest explanation for the growth of metE205 metP763 on high levels of D-methionine is that a second transport system, which has a higher $K_{\mathrm{m}}$ for $\mathrm{D}$-methionine than the metP system, is operating. It might be argued that the growth response of metE metP to a high concentration of D-methionine is due to the presence of L-methionine as an impurity. This is unlikely because in the plate tests, if the $D$-methionine preparations contained even small amounts of L-methionine, then the met $E$ $\operatorname{dad} A$ strains should respond as well as the metE metP strains. The results from the plate tests were confirmed by an experiment in liquid medium (not shown) similar to those in Fig. 1. MetE205 dadA52 grew on D-methionine at $100 \mu \mathrm{g} \mathrm{ml}^{-1}$ with a generation time of $310 \mathrm{~min}$, whereas metE205 metP763 showed a generation time of $160 \mathrm{~min}$ under similar conditions (Fig. $1 d$ ). Another possible explanation for the ability of metE metP strains to grow on high concentrations of D-methionine might be that all these strains possess a defect in the high- 
affinity L-methionine transport system which leads to a reduced affinity for D-methionine. This seems very unlikely to be true for all the metP mutants.

\section{Genetic studies on metP mutants}

Phage P22 HT int was successfully propagated on the following strains: metE205 metP760, metE205 metP761, metE205 metP765, metE205 metP766, metE205 metP767, metE205 metP1708, metE205 metP1709, metE205 metP1710, metE205 metP1711 and metE205 metP1712. Spot transductions were performed on MA + D-methionine $\left(10 \mu \mathrm{g} \mathrm{ml}^{-1}\right)$ using, as recipients, the 14 metE metP strains listed in Table 1 . The ability of the met $E$ met $P$ strains to act as recipients in transduction was checked using phage propagated on strains metE205 and LT2. Transducing ability was determined by spotting the phage on bacterial lawns of strain HfrK4 serA13 on MA+D-methionine. Strain metE205 metP762 was an extremely poor recipient. None of the homologous crosses yielded transductants, as anticipated. With all recipients except metE205 metP762 and metE205 metP764, phage grown on the metP mutants yielded fewer transductants than did phage grown on metE205 or LT2, suggesting that all the metP mutations lie in the same genetic region.

The mutants metP1708 and, possibly, metP763 could be due to deletions, since they yielded no recombinants when crossed with metP760, metP761, metP762, metP764, metP765, metP766 and metP1707. MetP1708, but not metP763, yielded recombinants with metP767, and therefore metP763 may be a longer deletion than metP1708. The suggestion that the metP763 mutation might be a deletion is difficult to reconcile with the observation that this mutation was both induced and reverted by ICR 191 B. Oeschger \& Hartman (1970), in a study of ICR-induced mutants requiring histidine, concluded that mutations which were reverted by ICR were 'minus' or 'plus' frameshifts. Those mutations which could have been short deletions were not reverted by ICR. However, this uncertainty about the nature of the metP763 mutation does not detract from its usefulness in the present work, since either deletions or frameshifts normally lead to completely defective gene products. The remaining mutants metP1709, met1710, metP1711 and metP1712 gave relatively large numbers of recombinants when crossed with metP1708 and are presumed to lie outside the deleted region.

To determine the approximate location of the metP gene on the $S$. typhimurium chromosome, a three-point conjugation cross was made between HfrA metP760 hisD23 galK50 (strain HU77) and proA46 leu-1003 purC7 ilv-405 (HU93). The leu and pro genes are located at 3 and 7 units, respectively, on the $S$. typhimurium linkage map (Sanderson \& Hartman, 1978). Pro $^{+} \mathrm{His}^{+}$recombinants were selected on $\mathrm{MA}+$ adenine + isoleucine+ leucine, and scored for inheritance of leu and metP. The percentages of the recombinant classes were: leut metP760 34.4\%; leu $u^{+}$metP $P^{+} 8.9 \%$; leu metP760 24.4\%; leu met $P^{+}$ $32.2 \%$ (from a total of 90 progeny). These results suggested that metP is located on the chromosome between the leu and pro $A$ genes, because on this sequence the minority leu ${ }^{+}$ $m e t P^{+}$class would require four crossovers and therefore would be rare.

Confirmation that the metP mutations were closely linked to the proA gene was obtained from P1-mediated transduction. P1-sensitive isolates were derived from metE205 metP760, metE205 metP762, metE205 metP763 and metE205 metP767 as described in Methods. Phage were propagated by induction of a P1 lysogen of the first strain, and by lytic infection in soft agar layers for the remaining strains. The phage preparations obtained with these strains were then used to transduce strain HU293, pro-624 hisD2421 ilvC401 metE338 ara-9 galE str-r, selecting for $\mathrm{Pro}^{+}$. Transductants were then replicated to MA + isoleucine+ valine + histidine $+\mathrm{D}$-methionine to determine the numbers of $\mathrm{MetP}^{+}$and $\mathrm{MetP}^{-}$recombinants. The resulting cotransduction frequencies between pro $^{+}$and $m e t P$ were as follows: metP760 0.3\% (393 scored); metP762 0.6\% (480 scored); metP763 0.3\% (648 scored); metP767 $1 \cdot 1 \%$ (268 scored). For each cross (except metP767) all the metP transductants (i.e. those which failed to grow on D-methionine) and an equal number of met $P^{+}$trans- 


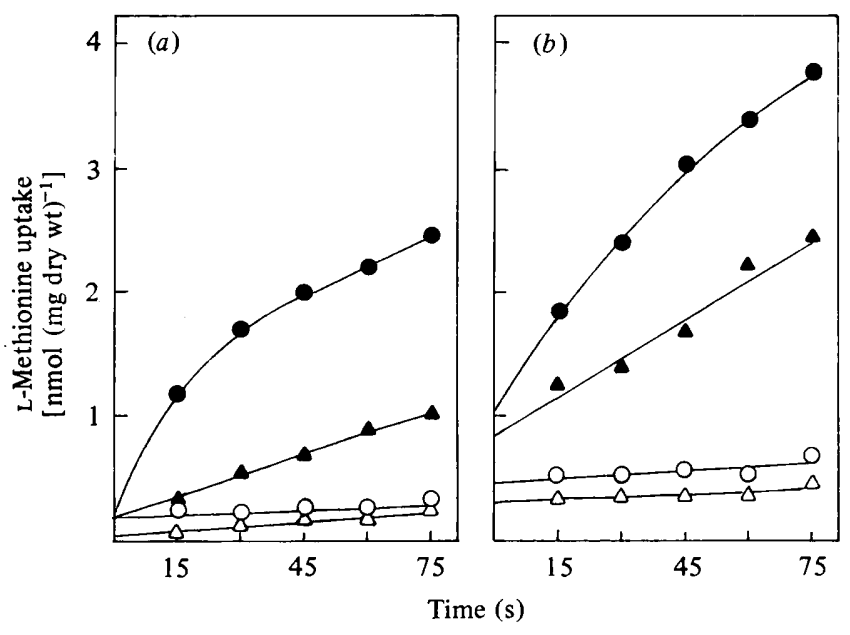

Fig. 2. Effect of sodium fluoride plus sodium azide on methionine uptake in the wild-type (HU322) and $m e t P 763$ (HU323) strains. Bacteria (final concentration $800 \mu \mathrm{g}^{\mathrm{dry}} \mathrm{wt} \mathrm{\textrm {ml } ^ { - 1 }}$ ) were preincubated with fluoride $(25 \mathrm{~mm})$ plus azide $(10 \mathrm{~mm})$ for $10 \mathrm{~min}$ before the addition of $\mathrm{L}-\left[{ }^{14} \mathrm{C}\right] \mathrm{methionine}$ [final concentration $50 \mu \mathrm{M}(a)$ or $\left.200 \mu \mathrm{M}(b), 5.6 \mu \mathrm{Ci} \mu \mathrm{mol}^{-1}\right]$ in a total volume of $1.2 \mathrm{ml}$. Samples $(0.2 \mathrm{ml})$ were taken and filtered at the indicated times. Wild-type control $(\odot)$, wild-type with fluoride plus azide $(\bigcirc)$, metP763 control $(\Delta)$, metP763 with fluoride plus azide $(\triangle)$.

ductants (i.e. those which grew on D-methionine) were picked on to fresh medium and replicated a second time on to media containing L- or D-methionine, to confirm the original scoring. In addition, the met $P$ transductants were tested and shown to contain one of the auxotrophic markers of the recipient strain. The final conclusion was that the metP class were genuine transductants, and that the met $P$ and pro genes are therefore sufficiently close on the chromosome to be carried on the Pl transduction fragment.

\section{Characterization of two methionine transport systems}

Time courses for the uptake of 50 or $200 \mu \mathrm{M}-\mathrm{L}-$ methionine by the metP+ and metP763 strains in the absence or presence of sodium fluoride plus sodium azide are shown in Fig. 2. At both concentrations of methionine, the rate of transport in the untreated wild-type strain started to decline after about $30 \mathrm{~s}$, whereas the rate of transport in the metP763 strain was constant over the $75 \mathrm{~s}$ assay period. As reported for E. coli by Kadner (1974), uptake in both strains was almost completely inhibited by sodium fluoride plus sodium azide, indicating that uptake is energized and not passive. In agreement with this conclusion, the omission of glucose from the assay medium reduced uptake of 50 or $200 \mu \mathrm{M}-\mathrm{L}-\mathrm{methionine}$ after $75 \mathrm{~s}$ by about $70 \%$ for $\mathrm{met}^{P^{+}}$and by about $55 \%$ for $\operatorname{met} P 763$.

Kinetic analysis was performed on the initial rates of uptake at increasing concentrations of L-methionine from 10 to $40 \mu \mathrm{M}$ in metP760 and metP763 (strains HU284 and HU323, respectively), and also in a wild-type strain (HU322) as a control (data not shown). The data for both metP mutants were linear over the concentration range studied, each yielding an apparent $K_{\mathrm{m}}$ of about $30 \mu \mathrm{M}$, and a $V_{\max }$ of $1.00 \mathrm{nmol} \mathrm{min}{ }^{-1}(\mathrm{mg} \text { dry wt) })^{-1}$. The mutation metP760 occurred spontaneously, whereas metP763 had been obtained in metE205 after treatment with the mutagen ICR (Table 1), although, as discussed above, it is not clear whether metP763 is a simple frameshift mutation or an extended deletion. But either type of mutation would be expected to result in a defective polypeptide and therefore it is likely that both metP760 and metP763 are completely defective in the high-affinity methionine transport system. The $V_{\max }$ for the wild-type was $2.32 \mathrm{nmol} \mathrm{min}^{-1}\left(\mathrm{mg}\right.$ dry wt) ${ }^{-1}$; this is composed of the $V_{\max }$ values for the high- and low-affinity systems. 


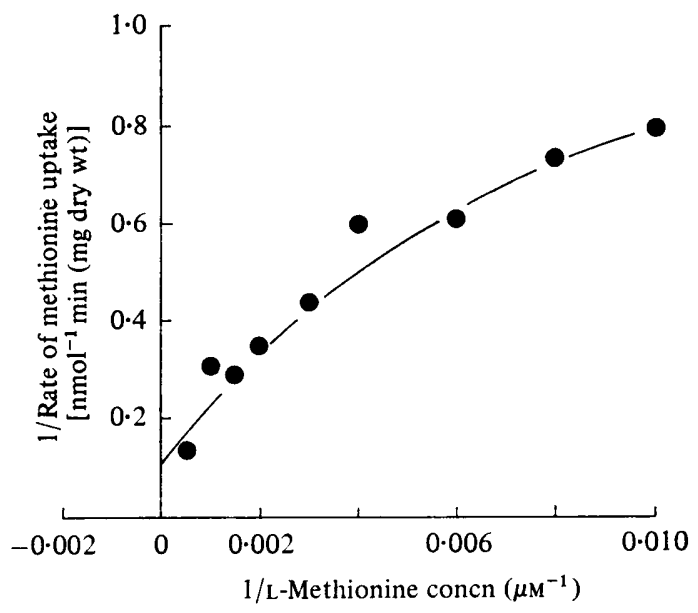

Fig. 3. Effect of external methionine concentration $(100 \mu \mathrm{M}$ to $2 \mathrm{~mm})$ on methionine uptake in metP763 (HU323). Uptake was determined from duplicate $0.6 \mathrm{ml}$ samples filtered at $30 \mathrm{~s}$. The final concentration of bacteria was $667 \mu \mathrm{g}$ dry wt ml-1. The increase in methionine concentration was achieved by adding unlabelled methionine to $100 \mu \mathrm{M}-\mathrm{L}-\left[{ }^{14} \mathrm{C}\right]$ methionine at $2.75 \mu \mathrm{Ci} \mu \mathrm{mol}^{-1}$.

The simplest explanation for the linearity of the double reciprocal plots for the metP mutant data is that, over the concentration range 10 to $40 \mu \mathrm{M}$, there is only one low-affinity methionine transport system operating. However, this type of kinetic analysis will not resolve two or more transport systems acting on the same substrate unless they have sufficiently different kinetic parameters (Dixon \& Webb, 1964). Also, it is possible that there are other systems with an even lower affinity for methionine than the system (or systems) detected in the above experiment; such a low-affinity system would be recognized only at very high methionine concentrations. Therefore methionine uptake was studied at concentrations from $100 \mu \mathrm{M}$ to $2 \mathrm{mM}$ (Fig. 3). A problem with working at these concentrations is that the toluene blanks are considerable when compared with the total uptake, and this reduces the accuracy of the estimates. For example, in the data shown in Fig. 3, the total uptake at $100 \mu \mathrm{M}$ methionine $\left(2.75 \mu \mathrm{Ci} \mu \mathrm{mol}^{-1}\right)$ was 1527 c.p.m., compared with the toluene blank of 147 c.p.m. (about $10 \%$ ), leaving 1380 c.p.m. accumulated by the bacteria [i.e. $\left.1.26 \mathrm{nmol} \mathrm{min}^{-1}(\mathrm{mg} \text { dry wt) })^{-1}\right]$, whereas at $2 \mathrm{mM}$ methionine $\left(0.14 \mu \mathrm{Ci}^{2} \mathrm{~mol}^{-1}\right)$ the total uptake was 608 c.p.m., compared with the toluene blank of 198 c.p.m. (about $33 \%$ ), giving 410 c.p.m. accumulated by the bacteria [i.e. $7.46 \mathrm{nmol} \mathrm{min}^{-1}(\mathrm{mg} \mathrm{dry} \mathrm{wt})^{-1}$ ]. But accepting these limitations, the data for the metP763 strain strongly suggested that the uptake above about $100 \mu \mathrm{M}$ increases rapidly, such that in this strain the $V_{\max }$ was about 5 to $10 \mathrm{nmol}$ $\min ^{-1}$ (mg dry wt) ${ }^{-1}$. It therefore seems possible that metP763 possesses two low-affinity methionine transport systems, and this suggestion is supported by the results to be presented in the later section on the inhibition of methionine uptake by leucine.

\section{Specificity of the methionine transport systems}

The effects of several amino acids and various compounds related to methionine on the uptake of $20 \mu \mathrm{M}$-methionine in a wild-type strain (HU322) and metP763 (HU323) are shown in Table 2. Compounds such as $S$-methylcysteine, $\alpha$-methylmethionine, norleucine and, to a lesser extent, leucine, isoleucine and valine, (and possibly phenylalanine and histidine) were more potent inhibitors of the low-affinity system than of the high-affinity system. Methionine methyl ester, methionine amide, $N$-acetylmethionine, glycylmethionine and $\alpha$-ketomethiolbutyric acid were strong inhibitors of the high-affinity system. Selenomethionine and, to a lesser extent, ethionine inhibited both systems, while D-methionine and methionine sulphoximine were poor inhibitors. 
Table 2. Effect of amino acids and compounds related to methionine on the uptake of $20 \mu \mathrm{M}$-methionine by the wild-type strain (HU322) and metP763 (HU323)

The final concentration of $\mathrm{L}$-methionine was $20 \mu \mathrm{M}\left(11 \cdot 2 \mu \mathrm{Ci} \mu \mathrm{mol}^{-1}\right)$ and the final concentration of bacteria was $400 \mu \mathrm{g}$ dry wt ml ${ }^{-1}$. Uptake was determined from duplicate $0.5 \mathrm{ml}$ samples (from two or three independent cultures) taken at $30 \mathrm{~s}$. Results are expressed as percentages of methionine uptake in the absence of inhibitors. Actual rates of uptake were: wild-type, $1.95 \pm 0.22 \mathrm{nmol} \mathrm{min} \mathrm{m}^{-1}$ (mg dry wt) $)^{-1}$ metP763, 0.40 $\pm 0.05 \mathrm{nmol} \mathrm{min}^{-1}$ (mg dry wt) $)^{-1}$.

\begin{tabular}{|c|c|c|c|}
\hline \multirow[b]{2}{*}{ Addition (concn, mM) } & & \multirow{2}{*}{$\begin{array}{l}\text { affinity } \\
\text { system* }\end{array}$} \\
\hline & metP $P^{+}$ & metP763 & \\
\hline None & 100 & 100 & 100 \\
\hline L-Methionine (2) & 3 & 12 & 1 \\
\hline D-Methionine (2) & 77 & 90 & 74 \\
\hline$N$-Acetyl-L-methionine (2) & 30 & 87 & 18 \\
\hline Glycyl-DL-methionine (2) & 37 & 77 & 30 \\
\hline$\alpha$-Ketomethiolbutyric acid (2) & 48 & 74 & 42 \\
\hline L-Methionine amide (2) & 14 & 40 & 10 \\
\hline L-Methionine methyl ester (2) & 13 & 45 & 6 \\
\hline$S$-Methyl-L-cysteine (2) & 86 & 42 & 98 \\
\hline Seleno-DL-methionine (2) & 5 & 15 & 3 \\
\hline L-Glutamine (2) & 85 & 86 & 85 \\
\hline L-Histidine (2) & 101 & 80 & 106 \\
\hline DL-Isoleucine (4) & 88 & 66 & 92 \\
\hline L-Leucine (2) & 93 & 62 & 104 \\
\hline L-Phenylalanine (2) & 101 & 76 & 110 \\
\hline L-Valine (2) & 96 & 68 & 104 \\
\hline$\alpha$-Methyl-DL-methionine (40) & 60 & 39 & 63 \\
\hline DL-Ethionine (40) & 14 & 5 & 18 \\
\hline L-Methionine-DL-sulphoximine (40) & 69 & 68 & 69 \\
\hline DL-Norleucine $(40)$ & 50 & 15 & 62 \\
\hline
\end{tabular}

* Calculated by subtracting the values for uptake in metP763 from $m e t P^{+}$.

Table 3. Effect of amino acids on the uptake of $100 \mu \mathrm{M}-$ methionine by metP763 (HU323)

The final concentration of $\mathrm{L}$-methionine was $100 \mu \mathrm{M}\left(5.6 \mu \mathrm{Ci} \mu \mathrm{mol}^{-1}\right)$ and the final concentration of bacteria was $667 \mu \mathrm{g}$ dry $\mathrm{wt} \mathrm{ml}^{-1}$. Uptake was determined from duplicate $0.6 \mathrm{ml}$ samples taken at $30 \mathrm{~s}$. Results derived from two experiments are expressed as percentages of methionine uptake in the absence of inhibitors. Actual rates of uptake were 1.01 and $0.94 \mathrm{nmol} \mathrm{min}^{-1}(\mathrm{mg} \mathrm{dry} \mathrm{wt})^{-1}$.

\begin{tabular}{l}
\multicolumn{1}{c}{ Addition (concn, mm) } \\
None \\
L-Methionine (10) \\
L-Leucine (10) \\
DL-Isoleucine (20) \\
L-Valine (10) \\
L-Phenylalanine (10) \\
L-Tryptophan (10) \\
L-Tyrosine (10) \\
L-Histidine (10) \\
L-Leucine (10)+ L-tryptophan (10)
\end{tabular}

Methionine
uptake $(\%)$
100
$8 \cdot 4$
55
65
60
52
65
70
71
43

An extended range of amino acids was tested for their effect on the uptake of $100 \mu \mathrm{M}$ methionine by metP763 (Table 3). The results confirmed that the branched-chain amino acids, the aromatic amino acids and histidine partially inhibited methionine uptake, and it is concluded that these amino acids compete for transport by a common system. The effect of adding leucine and tryptophan together was only slightly more inhibitory than adding either compound separately, and therefore it appears that the major part of the inhibition by the branched-chain and aromatic amino acids is exerted on the same methionine trans- 


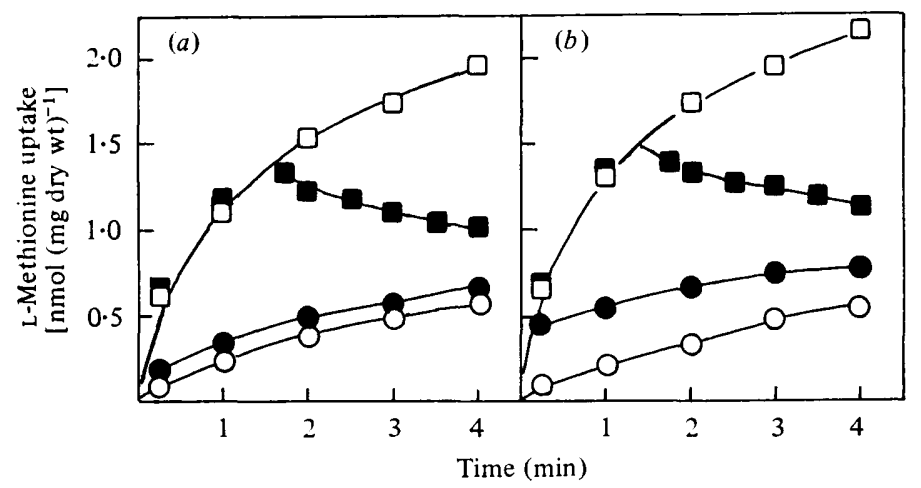

Fig. 4. Effects of DL-ethionine (a) and $\alpha$-ketomethiolbutyric acid $(b)$ on methionine uptake in the wild-type strain (HU322). The final concentration of bacteria was $50 \mu \mathrm{g}$ dry wt $\mathrm{ml}^{-1}$, and the $\mathrm{L}$ $\left.{ }^{[14} \mathrm{C}\right]$ methionine concentration was $1 \mu \mathrm{M}\left(56 \mu \mathrm{Ci} \mu \mathrm{mol}^{-1}\right)$ in a total volume of $2.0 \mathrm{ml}$. The inhibitors were added at the times indicated below to give final concentrations of $200 \mu \mathrm{M}$-DL-ethionine $(a)$ and $100 \mu \mathrm{M}$ - $\alpha$-ketomethiolbutyric acid $(b)$. Samples $(0.2 \mathrm{ml})$ were filtered at the indicated times. No inhibitor present $(\square)$, inhibitor added $1.5 \mathrm{~min}$ after the $\left[{ }^{14} \mathrm{C}\right]$ methionine $(\square)$, inhibitor added with the $\left[{ }^{14} \mathrm{C}\right]$ methionine $(\bigcirc)$, inhibitor added $1.5 \mathrm{~min}$ before the $\left[{ }^{14} \mathrm{C}\right]$ methionine $(O)$.

port system. However, it is possible that the inhibition observed at these high substrate concentrations is non-specific, caused by limitation of components shared by transport systems in general, e.g. the ATP-energy proton coupling system.

The group of compounds, typified by $S$-methylcysteine, which were shown in Table 2 to inhibit predominantly the low-affinity transport system, are unlikely to give rise to methionine in the bacterial cell, and therefore there is no reason to question that the inhibition observed is through competition for entry. However, compounds such as methionine methyl ester and $\alpha$-ketomethiolbutyric acid can readily give rise to L-methionine, as judged by their ability to support the growth of methionine auxotrophs. Kadner (1975) has shown that in $E$. coli, at least part of the inhibition observed with $\alpha$-ketomethiolbutyrate was due to transinhibition of $\left[{ }^{14} \mathrm{C}\right]$ methionine uptake by the L-methionine released from the inhibitor inside the cell, and we therefore examined the inhibition by this second group of compounds in more detail. Both ethionine (Fig. $4 a$ ) and $\alpha$-ketomethiolbutyric acid (Fig. $4 b$ ) inhibited uptake in the wild-type strain HU322 and caused slow efflux of methionine. Pre-incubation with $\alpha$-ketomethiolbutyric acid produced more inhibition in the earlier samples than was achieved by adding inhibitor and label simultaneously. This suggested that the intracellular pool of $\alpha$-ketomethiolbutyric acid or, more likely, the methionine derived from it, inhibited further uptake of $\mathrm{L}-\left[{ }^{14} \mathrm{C}\right]$ methionine.

The effect of D-methionine was also examined (results not shown). In one experiment using the wild-type, $100 \mu \mathrm{M}-\mathrm{D}$-methionine added with the $\mathrm{L}-\left[{ }^{14} \mathrm{C}\right]$ methionine inhibited uptake at $1 \mathrm{~min}$ by $32 \%$, whereas $100 \mu \mathrm{M}$-D-methionine added $3 \mathrm{~min}$ before the label resulted in $60 \%$ inhibition. A similar result was observed with the dadA52 strain (HU411) which is unable to convert $D$ - to $L$-methionine. However, when the experiments were repeated using a different batch of $\mathrm{D}$-methionine, addition of $\mathrm{D}$-methionine with the $\mathrm{L}-\left[{ }^{14} \mathrm{C}\right]$ methionine resulted in only $4 \%$ inhibition in either the wild-type or dadA52, and even the addition of D-methionine 3 min prior to the label resulted in only $17 \%$ or $24 \%$ inhibition in the wildtype or dadA52, respectively. It is therefore likely that all, or a high proportion, of the inhibitory effect of $\mathrm{D}$-methionine is due to a small amount of $\mathrm{L}$-methionine in the preparations. 


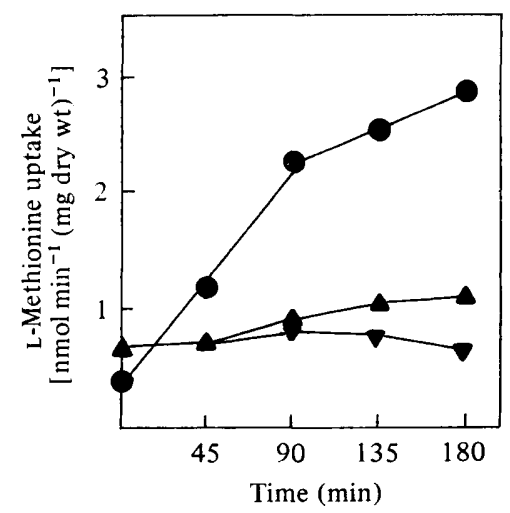

Fig. 5

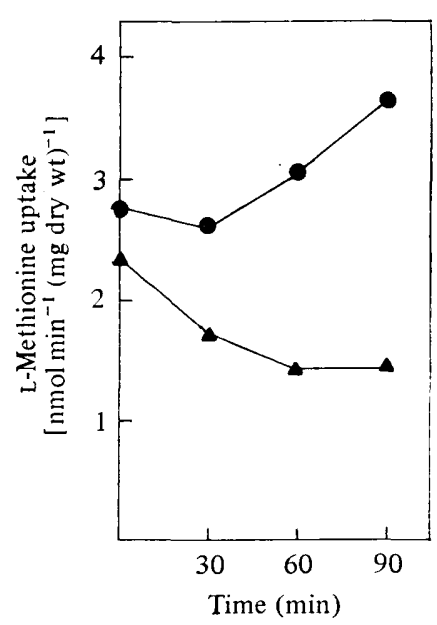

Fig. 6

Fig. 5. Derepression of methionine transport activity in the wild-type strain (HU322). Bacteria were grown in $\mathrm{MM}+\mathrm{L}$-methionine $\left(200 \mu \mathrm{g} \mathrm{ml}^{-1}\right)$. Washed cells were inoculated into $50 \mathrm{ml}$ of $\mathrm{MM}$ (๑), MM+ L-methionine $\left(200 \mu \mathrm{g} \mathrm{ml}^{-1}\right)(\boldsymbol{\Delta})$ or $\mathrm{MM}+\operatorname{chloramphenicol}\left(200 \mu \mathrm{g} \mathrm{ml}^{-1}\right)(\boldsymbol{\nabla})$. Samples were removed from the cultures at the indicated times and washed once. Methionine uptake was determined from duplicate $1 \mathrm{ml}$ samples filtered at $30 \mathrm{~s}$. The final concentration of bacteria was $50 \mu \mathrm{g}$ dry wt $\mathrm{ml}^{-1}$, and the $\mathrm{L}-\left[{ }^{14} \mathrm{C}\right]$ methionine concentration was $1 \mu \mathrm{M}\left(56 \mu \mathrm{Ci} \mu \mathrm{mol}^{-1}\right)$.

Fig. 6. Repression of methionine transport activity in the wild-type strain (HU322). Bacteria were grown in MM. Washed cultures were inoculated into $50 \mathrm{ml}$ of $\mathrm{MM}(\odot)$ or $\mathrm{MM}+\mathrm{L}-\mathrm{methionine}$ $\left(200 \mu \mathrm{g} \mathrm{ml}^{-1}\right)(\Delta)$. Methionine uptake was assayed as in Fig. 5.

\section{Repression of the high-affinity methionine transport system}

Growth of bacteria for several generations in the presence of L-methionine reduced uptake of $1 \mu \mathrm{M}-\mathrm{L}$ - $\left[{ }^{14} \mathrm{C}\right]$ methionine, whereas addition of L-methionine immediately before chloramphenicol (i.e. $30 \mathrm{~min}$ before harvesting started) had no effect. These results suggested that methionine might repress the synthesis of its own transport system and therefore the following experiments were performed. A culture of wild-type bacteria (strain HU322), grown for several generations in $\mathrm{MM}+\mathrm{L}-$ methionine $\left(200 \mu \mathrm{g} \mathrm{ml}^{-1}\right)$, was transferred into medium without methionine; there was an eightfold increase in the transport activity of the high-affinity system within $3 \mathrm{~h}$, and this increase was prevented by methionine or chloramphenicol (Fig. 5). It was therefore concluded that the increase in uptake required protein synthesis. It might be argued that the increase in transport activity in the culture transferred to $\mathrm{MM}$ was due to a gradual reduction in the size of the methionine pool, and that this reduction was prevented by chloramphenicol. Therefore the experiment was performed in the reverse direction and bacteria grown in $\mathrm{MM}$ were transferred into $\mathrm{MM}+\mathrm{L}$-methionine (Fig. 6). Under these conditions, transport activity declined gradually to about $60 \%$ of the initial value after $1 \mathrm{~h}$; in a control culture transferred from MM to MM, transport activity actually increased by $34 \%$ in $1.5 \mathrm{~h}$. It seems very unlikely that it takes this time to establish the methionine pool, and from these results and those in Fig. 5, it is concluded that a substantial proportion of the reduction in transport after growth in methionine is due to a reduced synthesis of the high-affinity system.

We found no evidence for repression of methionine transport activity in strain metP763 (HU323). In one series of experiments, uptake of $42 \mu \mathrm{M}-\mathrm{L}$-methionine was $0.83 \pm 0.13 \mathrm{nmol}$ $\min ^{-1}(\mathrm{mg} \mathrm{dry} \mathrm{wt})^{-1}$ in cultures grown without L-methionine, and $0.71 \pm 0.05 \mathrm{nmol} \mathrm{min}^{-1}$ (mg dry wt) $)^{-1}$ in cultures grown in the presence of $20 \mu \mathrm{g} \mathrm{L}$-methionine $\mathrm{ml}^{-1}$. In a second series of experiments, uptake of $42 \mu \mathrm{M}$-L-methionine was $1.02 \pm 0.18 \mathrm{nmol} \mathrm{min}{ }^{-1}$ (mg dry wt) $)^{-1}$ in cultures grown without $\mathrm{L}$-methionine, and $0.96 \pm 0.10 \mathrm{nmol} \mathrm{min}^{-1}(\mathrm{mg} \mathrm{dry} \mathrm{wt})^{-1}$ in 
cultures grown in the presence of $200 \mu \mathrm{g} \mathrm{L}$-methionine $\mathrm{ml}^{-1}$ (each value is the average of duplicate determinations on two to four independent cultures).

\section{Inhibition of methionine and leucine transport}

Several recent reports indicate that methionine affects the activity of the leucine, isoleucine and valine transport systems. At least three different branched-chain amino acid transport systems have been identified in $E$. coli K12: a 'high-affinity' leucine-specific system (LS); a 'very high-affinity' leucine-isoleucine-valine system (LIV-I); and a 'high-affinity' leucineisoleucine-valine system (LIV-II) (Rahmanian et al., 1973; Guardiola et al., 1974a, b; Wood, 1975; Iaccarino et al., 1978). The high-affinity LIV-II system is actually the sum of two different systems which apparently work in parallel (Guardiola et al., 1974b). The LS and LIV-I systems are strongly repressed by growth on leucine (or several other amino acids). The LIV-II systems may be repressed by leucine, depending on the strain of $E$. coli used (Wood, 1975). Guardiola et al. $(1974 a, b)$ showed that in $E$. coli the activity of the LIV-I transport system was inhibited by methionine and its activity was decreased by growth of bacteria in the presence of methionine. Templeton \& Savageau $(1974 a, b)$ found that in $E$. coli leucine, and possibly methionine, inhibited the transport of homoserine, and leucine and methionine each repressed the synthesis of the homoserine transport system. Wood (1975) quoted unpublished work which showed that growth of $E$. coli in medium containing L-methionine $\left(50 \mu \mathrm{g} \mathrm{ml}^{-1}\right)$ repressed the leucine-specific system.

We therefore considered the possibility that part of the low-affinity methionine transport in S. typhimurium was carried out by a leucine or general branched-chain amino acid transport system. To determine what proportion of methionine transport was inhibited by leucine, the effect of increasing concentrations of L-leucine on the uptake of $20 \mu \mathrm{M}-\mathrm{L}-$ methionine by the metP760 strain was determined (data not shown). Only about $35 \%$ of methionine uptake could be inhibited, and this was achieved with $200 \mu \mathrm{M}-\mathrm{L}-\mathrm{leucine}$; increasing the leucine concentration 10 -fold to $2 \mathrm{mM}$ did not significantly increase the degree of inhibition. The simplest explanation of these results is that the methionine transport activity remaining in the met $P$ mutants is due to two low-affinity systems, only one of which is inhibited by leucine. We next determined the effect of a high concentration of L-leucine on methionine uptake in strain metP763 over a range of methionine concentrations (Fig. 7). Leucine inhibited a significant proportion of methionine transport, and this proportion increased with increasing methionine concentration. If leucine were competitively inhibiting methionine transport, the degree of inhibition should decrease as the methionine concentration is increased. Therefore these results again agreed with the hypothesis that there are two low-affinity methionine transport systems. Kinetic analysis of the results obtained in the presence of leucine (Fig. 7, plot B) gave the following values: $K_{\mathrm{m}} 50 \mu \mathrm{M}, V_{\max } 0.89 \mathrm{nmol}$ $\min ^{-1}$ (mg dry wt) ${ }^{-1}$. However, in the absence of leucine (Fig. 7, plot A) there was a rapid rise in the rate of uptake at external methionine concentrations greater than about $100 \mu \mathrm{M}$ (reciprocal of concentration $0.01 \mu \mathrm{M}^{-1}$ ). It is not possible to tell from the present data whether this additional component of uptake is due to diffusion or to a transport system with an extremely high $K_{\mathrm{m}}$ for methionine, but the fact that this uptake is leucine-sensitive strongly suggests that this is a carrier-mediated process. Analysis of the data obtained in the absence of leucine by the iterative procedure (Osmundsen, 1975) yielded the following values for the low-affinity system: $K_{\mathrm{m}} 24 \mu \mathrm{M}, V_{\max } 0.66 \mathrm{nmol} \mathrm{min}^{-1}\left(\mathrm{mg}\right.$ dry wt) ${ }^{-1}$; the values for the very low-affinity system are only approximate, since they had high standard errors: $K_{\mathrm{m}} 1.8 \mathrm{~mm}$, $V_{\max } 9 \mathrm{nmol} \mathrm{m^{-1 }}(\mathrm{mg} \text { dry } \mathrm{wt})^{-1}$. Since leucine partially inhibited methionine uptake in metP763, the effect of methionine on the uptake of leucine in this strain and the wild-type was investigated (Table 4). A 100-fold excess of methionine reduced the uptake of $10 \mu \mathrm{M}$ leucine to $66 \%$ of the control value in both strains, suggesting that there is a component of leucine transport which also transports methionine. A smaller degree of inhibition was also seen at $0 \cdot 1$ and $1 \mu \mathrm{M}$-leucine. Since the results for the wild-type strain were almost identical 


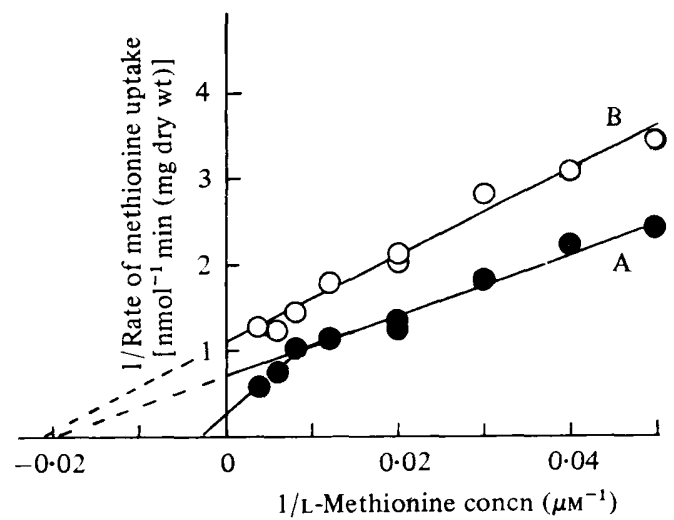

Fig. 7. Effect of external methionine concentration on methionine uptake by metP763 (HU323) in the absence $(\bigcirc)$ or presence $(\bigcirc)$ of $3.33 \mathrm{~mm}$-leucine. Uptake was determined from $0.6 \mathrm{ml}$ samples filtered at $30 \mathrm{~s}$. The final concentration of bacteria was $800 \mu \mathrm{g}$ dry wt $\mathrm{ml}^{-1}$, the specific activity of $\mathrm{L}-\left[{ }^{14} \mathrm{C}\right]$ methionine was $2 \cdot 8 \mu \mathrm{Ci} \mu \mathrm{mol}^{-1}$.

Table 4. Effect of methionine on the uptake of leucine or tryptophan by the wild-type strain (HU322) and metP763 (HU323)

The final concentration of bacteria was $100 \mu \mathrm{g}$ dry wt $\mathrm{ml}^{-1}$. Uptake was determined from duplicate $1.0 \mathrm{ml}$ samples taken at $30 \mathrm{~s}$.

\begin{tabular}{ccc}
\multicolumn{4}{c}{ Concn $(\mu \mathrm{M})$} & \multicolumn{1}{c}{ L-Leucine } & L-Tryptophan & L-Methionine \\
$0 \cdot 1$ & - & - \\
0.1 & - & $10 \cdot 0$ \\
1.0 & - & $\overline{-}$ \\
1.0 & - & - \\
10.0 & - & $100 \cdot 0$ \\
10.0 & - & - \\
- & 0.5 & $100 \cdot 0$
\end{tabular}

\begin{tabular}{|c|c|c|c|}
\hline \multicolumn{4}{|c|}{$\begin{array}{l}\text { Uptake of leucine or tryptophan } \\
\left.\text { [nmol } \min ^{-1}(\mathrm{mg} \text { dry wt })^{-1}\right]\end{array}$} \\
\hline \multicolumn{2}{|c|}{ met $P^{+}$} & \multicolumn{2}{|c|}{ metP763 } \\
\hline Uptake & $\%$ & Uptake & $\%$ \\
\hline $0 \cdot 13$ & 100 & 0.118 & 100 \\
\hline 0.09 & 69 & $0 \cdot 110$ & 93 \\
\hline 0.65 & 100 & 0.69 & 100 \\
\hline 0.58 & 89 & $0 \cdot 61$ & 88 \\
\hline $2 \cdot 39$ & 100 & $2 \cdot 47$ & 100 \\
\hline $1 \cdot 57$ & 66 & $1 \cdot 63$ & 66 \\
\hline 0.72 & 100 & 0.65 & 100 \\
\hline 0.68 & 94 & 0.63 & 97 \\
\hline
\end{tabular}

with those for the metP mutant, the metP transport system does not transport leucine, in agreement with the results of Table 2 and Ayling \& Bridgeland (1972).

We next investigated which of the branched-chain amino acid transport systems was inhibited by methionine. In E. coli, several workers have shown that threonine inhibits the 'very high-affinity' (LIV-I) system. In addition, norleucine inhibits the 'high-affinity' (LIV-II) systems (Wood, 1975) and threonine specifically inhibits one of the two "highaffinity' components (Guardiola et al., 1974b). If the situation were similar in S. typhimurium, it might be possible to determine which system was inhibited by using combinations of methionine, threonine and norleucine as inhibitors, plus isoleucine which would inhibit all except the 'leucine-specific' activity. Bacteria were grown in the absence or presence of leucine to repress the LS and LIV-I systems (Table 5). The activity of the LS system accounts for only a few per cent of the total leucine uptake. In unrepressed cells, the activity resistant to norleucine, which is taken to be the activity of the LIV-I system, accounted for about $20 \%$ of the total uptake, while the activity resistant to threonine, taken to be part of the LIV-II activity, accounted for about $60 \%$ of the total uptake. Threonine was a weaker inhibitor than norleucine of uptake in repressed cells, presumably because of repression of the LIV-I system. However, in unrepressed or repressed cells, the effect of methionine plus threonine or methionine plus norleucine was little different from that of either amino acid alone, and 
Table 5. Effect of inhibitors on the uptake of leucine by metP763 (HU323)

Bacteria were grown in the presence or absence of $50 \mu \mathrm{g} \mathrm{L}$-leucine $\mathrm{ml}^{-1}$. Other details as in Table 4.

\begin{tabular}{|c|c|c|c|c|}
\hline \multirow{3}{*}{$\begin{array}{c}\text { Inhibitor } \\
\text { (concn, mM) }\end{array}$} & \multicolumn{4}{|c|}{$\begin{array}{l}\text { Uptake of } 10 \mu \mathrm{M} \text {-L-leucine } \\
{\left[\text { nmol min } \text { ming }^{-1}(\mathrm{mg} \text { dry } \mathrm{wt})^{-1} \text { ] }\right.}\end{array}$} \\
\hline & \multicolumn{2}{|c|}{ Unrepressed } & \multicolumn{2}{|c|}{ Repressed } \\
\hline & Uptake & $\%$ of control & Uptake & $\%$ of control \\
\hline None & $2 \cdot 12$ & 100 & 0.77 & 100 \\
\hline L-Methionine (1) & 1.05 & 50 & 0.39 & 51 \\
\hline DL-Isoleucine (2) & $0 \cdot 10$ & 5 & 0.00 & 0 \\
\hline L-Threonine (1) & $1 \cdot 21$ & 57 & 0.57 & 74 \\
\hline DL-Norleucine (2) & 0.46 & 22 & $0 \cdot 16$ & 21 \\
\hline $\begin{array}{l}\text { L-Methionine (1) + } \\
\text { DL-isoleucine (2) }\end{array}$ & 0.07 & 3 & 0.08 & 10 \\
\hline $\begin{array}{l}\text { L-Methionine (1)+ } \\
\text { L-threonine (1) }\end{array}$ & 0.85 & 40 & $0 \cdot 39$ & 51 \\
\hline $\begin{array}{l}\text { L-Methionine (1)+ } \\
\text { DL-norleucine (2) }\end{array}$ & $0 \cdot 41$ & 19 & $0 \cdot 11$ & 14 \\
\hline
\end{tabular}

thus, although it is clear that methionine inhibits a LIV rather than the LS system, it is not possible to conclude which of the LIV systems is likely to transport methionine. Because the aromatic amino acids weakly inhibited methionine uptake (Tables 2 and 3), the effect of methionine on the uptake of tryptophan was tested. Ames (1964) has shown that tryptophan is transported by the general aromatic amino acid transport system $\left(K_{\mathrm{m}} 0.5 \mu \mathrm{M}\right)$, along with phenylalanine, tyrosine and histidine. In addition, tryptophan is transported by a specific system $\left(K_{\mathrm{m}} 0 \cdot 1\right.$ to $\left.1 \cdot 0 \mu \mathrm{M}\right)$. The uptake of tryptophan was similar in both the wildtype and metP763 strains, and a 200 -fold excess of methionine had no effect on uptake (Table 4). Therefore, there is no evidence from these results to suggest that methionine is transported by the general aromatic amino acid transport system.

\section{Effects of methionine regulatory mutations on methionine transport}

MetJ mutants, which are resistant to the methionine analogue ethionine, have been isolated in S. typhimurium (Lawrence et al., 1968) and E. coli (Holloway et al., 1970). The properties of these mutants have led to the suggestion that met $J$ may be the structural gene for the methionine repressor (Chater, 1970; Holloway et al., 1970). The mutants have constitutive synthesis of the methionine biosynthetic enzymes and also of $S$-adenosylmethionine synthetase, the enzyme which converts methionine into $S$-adenosylmethionine (SAM) (Hobson \& Smith, 1973; Holloway et al., 1970). As a consequence, the mutants excrete methionine and have been shown to have increased methionine pools in $S$. typhimurium (Hobson, 1974). Kadner (1975) has shown that in $E$. coli the rate of methionine transport was very high in a met $B$ met $J$ strain with a block in methionine biosynthesis, when it was starved for exogenous methionine. This was interpreted as support for feedback control of methionine transport by intracellular methionine; it was suggested that in the met $B$ met $J$ strain, under conditions of methionine starvation, the methionine pool was rapidly reduced by constitutive SAM synthetase activity, and could not be replenished because of the block in methionine biosynthesis. We have therefore tested the effect of a met $J$ mutation on transport in $S$. typhimurium. A metB met $J$ strain (HU62) was grown in $\mathrm{MM}+\mathrm{L}$-methionine and then transferred to medium without methionine. The culture was assayed for methionine uptake (Fig. $8 a$ ). Even in the earliest samples, transport was greater in met $B$ met $J$ than in the $m e t B$, met $J$ or wild-type strains, and it increased until it was about five times the control value. The very high level of transport reached by met $B$ met $J$ suggests that met $J$ alone results in derepression of the metP product; in the absence of the met $B$ mutation, this increase is masked by the raised intracellular methionine pool. 


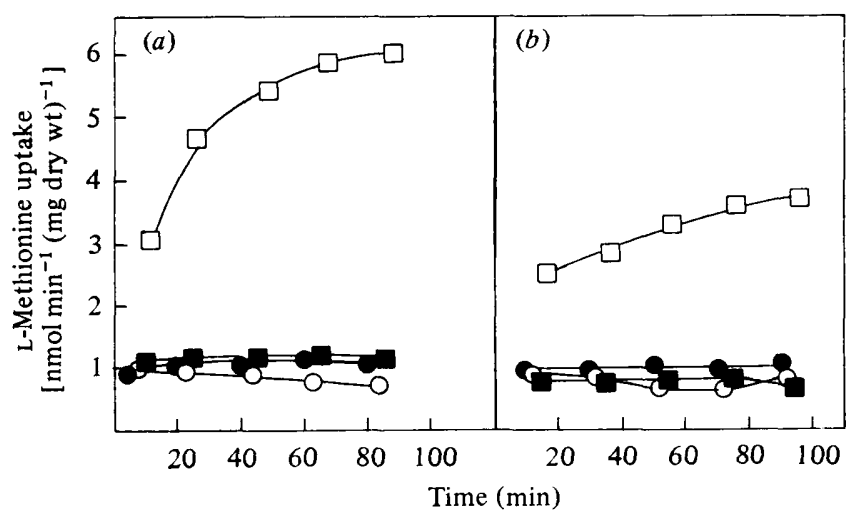

Fig. 8. Effect of metJ $(a)$ and $\operatorname{met} K(b)$ mutations on the rate of methionine uptake. Bacteria were grown in $\mathrm{MM}+\mathrm{L}-$ methionine $\left(20 \mu \mathrm{g} \mathrm{ml}^{-1}\right)$, treated with chloramphenicol $\left(200 \mu \mathrm{g} \mathrm{ml}^{-1}\right)$ and harvested in the usual way. The suspensions were diluted with $\mathrm{CM}$ to $150 \mu \mathrm{g}$ dry wt ml $\mathrm{m}^{-1}$ and left at room temperature $\left(20\right.$ to $23^{\circ} \mathrm{C}$ ). At the indicated times, $0.2 \mathrm{ml}$ samples were added to $0.4 \mathrm{ml}$ $\mathrm{CM}+\mathrm{L}-\left[{ }^{14} \mathrm{C}\right]$ methionine (final concentration $1 \mu \mathrm{M}, 56 \mu \mathrm{Ci} \mu \mathrm{mol}^{-1}$ ). The mixture was filtered at 30 s. (a) MetB metJ $^{+}$(HU409) (O), metB ${ }^{+}$metJ744 (HU410) (O), metB23 met $J^{+}$(HU33) ( $\square$ ), metB23 metJ744 (HU62) ( $\square$ ). (b) MetB ${ }^{+}$metK ${ }^{+}$(HU405) (O), metB ${ }^{+}$metK725 (HU404) (O), metB23 met $\mathrm{K}^{+}$(HU403) ( $\square$ ), metB23 metK725 (HU402) ( $\square$ ). (Some points have been omitted for clarity.)

Methionine transport was also studied in two met $K$ mutants. Preliminary results had shown that a met A met $K$ strain possessed an increased rate of transport (Ayling \& Bridgeland, 1972). Those met $K$ mutants which excrete methionine show constitutive synthesis of the methionine biosynthetic enzymes (Lawrence et al., 1968). All excreting mutants except metK721 have reduced or undetectable SAM synthetase activities; metK721 is atypical in that it has wild-type SAM synthetase activity when the metabolism of SAM is blocked by potassium cyanide in the assay medium (Hobson \& Smith, 1973). It has been suggested that $S$. typhimurium possesses an alternative route for the synthesis of SAM in addition to SAM synthetase, to account for the properties of these mutants; for example, excreting and nonexcreting met $K$ strains have as high intracellular concentrations of SAM as the wild-type (Hobson, 1976). We have studied the effects of met $K 721$ and metK 725 on methionine transport, and typical results for metK725 are shown in Fig. 8(b). MetB23 metK725 (HU402) showed a higher rate of transport than the met $B$, met $K$ or wild-type strains. This behaviour was similar to that of metB metJ, although the final level attained was lower. Similar results were found for the strains carrying metK721.

The interpretation of the results with the met $K$ strains is difficult. It is tempting to suggest that the increase in uptake in $\operatorname{met} B \operatorname{met} K$, like met $B$ met $J$, is also due to a depletion of the methionine pool. But it is not clear how this could occur. It is not likely to be due to the increased conversion of methionine into SAM in met $K$ mutants because Hobson (1976) has shown that whole cells of met $K$ strains carrying methionine auxotrophic lesions, when grown in $100 \mu \mathrm{M}$-methionine, converted methionine into SAM at the same rate as the auxotroph.

\section{DISCUSSION}

Earlier work (Ayling \& Bridgeland, 1972) established the existence of at least two transport systems with different affinities for L-methionine in S. typhimurium. Mutants isolated as resistant to the analogues $\alpha$-methylmethionine or methionine sulphoximine were defective in the high-affinity system and were designated metP (although it was not certain that they mapped in the same gene). The present studies provide additional information on the genetics and biochemistry of the metP system and confirm that there is at least one low- 
affinity system. All the metP mutants which have been studied seem to be similar to the met $D$ mutants in $E$. coli. Cooper (1966) first isolated mutants of this type in $E$. coli; the mutations were located at about $10 \mathrm{~min}$ on the $E$. coli chromosome map. It was suggested that the lesion was in the enzyme which converted D- to L-methionine, but Kadner (1974) and Kadner \& Watson (1974) established that metD mutants of E. coli lacked a high-affinity L-methionine transport system. They also isolated a double mutant which not only lacked the high-affinity system, but which was also partially defective in the low-affinity system. Mutations in the low-affinity system were designated metP, so that this gene symbol is at present used for different transport systems in $E$. coli and $S$. typhimurium. It is interesting that the met $P$ mutations in the high-affinity system of $S$. typhimurium may affect the activity of the low-affinity glutamine transport system (J. Poland, personal communication).

Although the $S$. typhimurium mutations were initially selected either for resistance to $\alpha$-methylmethionine (AM), for resistance to methionine sulphoximine (METX), or for preventing growth of methionine auxotrophs on D-methionine, all mutant strains seem to have very similar growth characteristics, methionine transport defects and genetic properties. Four of the metP mutations (metP760, metP762, metP763 and metP767) were shown to be weakly linked in Pl-mediated transduction with a pro gene. Spot transduction experiments indicated that metP760, metP761, metP762, metP763, metP764, metP765, metP766, metP767, metP1707 and metP1708 were closely linked, although it was not possible to decide whether they were all located in the same gene. It was not clear whether mutants metP1709, metP1710, metP1711 and metP1712 were in the same region as the other metP mutants. The simplest interpretation is that there is a single high-affinity L-methionine transport system, which also transports D-methionine at a sufficiently high rate to satisfy the methionine requirements of the bacterium. This system may be complex, because although all the metP mutants are defective in the transport of $\mathrm{L}$ - and $\mathrm{D}$-methionine, Dmethionine is an extremely poor inhibitor of L-methionine transport. Thus, as has been discussed by Kadner (1977) with reference to the metD mutants in $E$. coli, the metP mutants may lack a component which is involved in L- and D-methionine transport, but there may be additional components which are specific for each isomer. Revertants induced by NG in strain metB23 metP760 which have regained the ability to grow on D-methionine at $10 \mu \mathrm{g} \mathrm{ml}^{-1}$ are interesting because they do not have the full methionine transport activity of met $P^{+}$ strains. Certain of these revertants apparently contain two mutations, one of which restores ability to grow on D-methionine, and another which results in reduced glutamine transport (J. Poland, personal communication). It is not yet clear what relationship, if any, exists between growth on D-methionine and the glutamine transport defect.

Kinetic studies on methionine transport at concentrations from 10 to $40 \mu \mathrm{M}$ could be interpreted most simply as meaning that the metP760 and metP763 mutants possessed a single low-affinity L-methionine transport system with a $K_{\mathrm{m}}$ of about $30 \mu \mathrm{M}$ and a $V_{\max }$ of $1.00 \mathrm{nmol} \mathrm{min}^{-1}$ (mg dry wt) ${ }^{-1}$. However, the increase in the rate of uptake observed at methionine concentrations up to 1 to $2 \mathrm{~mm}$ suggested that there might be two low-affinity systems (Fig. 3). This idea was supported by the results of experiments on the effect of leucine on methionine transport in metP763. At low concentrations of L- $\left[{ }^{4} \mathrm{C}\right]$ methionine $(20 \mu \mathrm{M})$, leucine inhibited only about $35 \%$ of the total uptake and the degree of inhibition could not be increased by raising the leucine concentration. In a wild-type strain under similar conditions, the inhibition by leucine was hardly detectable because at this concentration of L-methionine, the contribution to uptake by the high-affinity system was about five times that of the low-affinity component, and effectively masked the leucine effect. But it was clear that as the rate of methionine transport increased with increasing external methionine concentrations, so the proportion of transport that could be inhibited by leucine also increased (Fig. 7).

It is suggested on the basis of the data in Fig. 7 that there are two low-affinity transport systems, only one of which is inhibited by leucine. It is not known whether the leucine- 
sensitive methionine system actually transports leucine into the bacterium, but it is clear that methionine does inhibit leucine transport (Table 4). We have attempted to determine whether this system corresponds to one of the branched-chain systems already identified in E. coli (Rahmanian et al., 1973; Guardiola et al., 1974a, b; Wood, 1975) and in S. typhimurium (Kiritani, 1974). Wood(1975) showed that norleucine only inhibited leucine uptake by the leucine-isoleucine-valine (LIV-II) system; since this analogue inhibits a substantial portion of methionine uptake in metP763 (Table 2), the leucine-sensitive system in S. typhimurium may be equivalent to the LIV-II system. The results in Table 5 showed that the leucinespecific (LS) system plays a minor role in leucine transport, and therefore if methionine is transported by a leucine system, it must be an LIV-I or LIV-II system. It was not possible to decide from the inhibition studies with norleucine and threonine whether the LIV-I or LIV-II system is likely to function as a methionine transport system.

To verify the suggestion that there are two low-affinity methionine transport systems will require the isolation of mutants in each of these systems. We have isolated mutants from met $B 23$ metP760 which fail to grow on L-methionine $\left(10 \mu \mathrm{g} \mathrm{ml}^{-1}\right)$ in the presence of leucine. But these mutants also fail to grow on L-methionine in the presence of glycylleucine and are therefore not likely to be altered in leucine transport, since amino acids and dipeptides enter the bacterium by different transport systems (Payne \& Gilvarg, 1971).

Since metE metP strains, but not metE dadA strains, can grow on D-methionine when the concentration is increased to $100 \mu \mathrm{g} \mathrm{ml}^{-1}(670 \mu \mathrm{M})$, there is presumably a second system which transports D-methionine. This system may be one or both of the low-affinity L-methionine systems, since D-methionine inhibits L-methionine transport (Table 2).

Methionine transport in $S$. typhimurium, as in E. coli, seems to be subject to transinhibition by methionine in the intracellular pool. The inhibitory effects on methionine transport of many compounds such as $\alpha$-ketomethiolbutyric acid can be satisfactorily explained in terms of transinhibition after their conversion to methionine inside the bacterium. The results with the met $B$ met $J$ strain (Fig. $8 a$ ) can be explained in terms of control by transinhibition and repression, but the results with met $B$ metK721 and metB metK725 (Fig. $8 b$ ) are difficult to explain. It is possible that the met $K$ mutations result in the derepression of an enzyme which converts methionine into a compound other than SAM. Another possibility is that SAM, rather than methionine, acts as the co-repressor in the repression of synthesis of the $m e t P$ transport system, as happens with the methionine biosynthetic enzymes. In addition to this feedback inhibition, the activity of the metP system, but not the low-affinity system(s) to any extent, is reduced by growth in the presence of methionine (Figs 5 and 6). Our experiments argue against, but do not completely exclude, the possibility that this reduction is due to slow changes in the intracellular methionine concentration. However, it is more likely that methionine, or perhaps a product of methionine, reduces the activity of the met $P$ system, either by repressing its synthesis or perhaps by increasing its rate of breakdown. Whatever the mechanism of this effect it suggests that the major function of the met $P$ system is to scavenge methionine which has been lost from the bacterial cell into the environment. When the external concentration of methionine is high, the activity of the met $P$ system would no longer be required. It is not yet clear what is the real function of the low-affinity methionine transport systems.

We wish to thank Mrs Christine Lonsdale and Miss Linda Kirk for excellent technical assistance, Dr J. E. Brenchley, Dr E. S. Bridgeland and Dr M. Iaccarino for critically reading the manuscript, Dr D. R. Threlfall for advice on the use of L-amino acid oxidase, Dr H. Osmundsen for providing and Mr J. D. Healey for running the computer programme, and those who supplied strains. P.D.A. gratefully acknowledges the receipt of a short-term fellowship of the European Molecular Biology Organization. 


\section{REFERENCES}

AMEs, G. F. (1964). Uptake of amino acids by Salmonella typhimurium. Archives of Biochemistry and Biophysics 104, 1-18.

AMEs, G. F. \& Roth, J. R. (1968). Histidine and aromatic permeases of Salmonella typhimurium. Journal of Bacteriology 96, 1742-1749.

AYling, P. D. (1977). Low-affinity methionine transport systems in Salmonella typhimurium. Proceedings of the Society for General Microbio$\log y 5,24$.

Ayling, P. D. \& Bridgeland, E. S. (1972). Methionine transport in wild-type and transportdefective mutants of Salmonella typhimurium. Journal of General Microbiology 73, 127-141.

Ayling, P. D. \& Chater, K. F. (1968). The sequence of four structural and two regulatory methionine genes in the Salmonella typhimurium linkage map. Genetical Research 12, 341-354.

Betteridge, P. R. \& Ayling, P. D. (1975). The role of methionine transport-defective mutations in resistance to methionine sulphoximine in Salmonella typhimurium. Molecular and General Genetics 138, 41-52.

ChATER, K. F. (1970). Dominance of the wild-type alleles of methionine regulatory genes in Salmonella typhimurium. Journal of General Microbiology 63, 95-109.

COOPER, S. (1966). Utilization of D-methionine by Escherichia coli. Journal of Bacteriology 92, 328332.

Dixon, M. \& Webb, E. C. (1964). In Enzymes, 2nd edn, pp. 87-90. London: Longmans.

ENomoto, M. \& Stocker, B. A. D. (1974). Transduction by phage $\mathrm{P} 1 \mathrm{kc}$ in Salmonella typhimurium. Virology 60, 503-514.

Guardiola, J., De Felice, M., Klopotowski, T. \& IACCARINO, M. (1974a). Multiplicity of isoleucine, leucine, and valine transport systems in Escherichia coli K-12. Journal of Bacteriology 117, 382-392.

Guardiola, J., De Felice, M., Klopotowski, T. \& IACCARINO, M. (1974b). Mutations affecting the different transport systems for isoleucine, leucine, and valine in Escherichia coli K-12. Journal of Bacteriology 117, 393-405.

Hobson, A. C. (1974). The regulation of methionine and $S$-adenosylmethionine biosynthesis and utilization in mutants of Salmonella typhimurium with defects in $S$-adenosylmethionine synthetase. Molecular and General Genetics 131, 263-273.

Hobson, A. C. (1976). The synthesis of $S$-adenosylmethionine by mutants with defects in $S$ adenosylmethionine synthetase. Molecular and General Genetics 144, 87-95.

Hobson, A. C. \& SMith, D. A. (1973). S-Adenosylmethionine synthetase in methionine regulatory mutants of Salmonella typhimurium. Molecular and General Genetics 126, 7-18.

Holloway, C. T., Greene, R. C. \& Su, C.-H. (1970). Regulation of $S$-adenosylmethionine synthetase in Escherichia coli. Journal of Bacteriology 104, 734-747.

Iaccarino, M., Guardiola, J. \& De Felice, M. (1978). On the permeability of biological membranes. Journal of Membrane Science 3, 287-302.
KADNER, R. J. (1974). Transport systems for Lmethionine in Escherichia coli. Journal of Bacteriology 117, 232-241.

KADNER, R. J. (1975). Regulation of methionine transport activity in Escherichia coli. Journal of Bacteriology 122, 110-119.

KADNER, R. J. (1977). Transport and utilization of D-methionine and other methionine sources in Escherichia coli. Journal of Bacteriology 129, 207-216.

KADNER, R. J. \& WATSON, W. J. (1974). Methionine transport in Escherichia coli: physiological and genetic evidence for two uptake systems. Journal of Bacteriology 119, 401-409.

KIRITANI, K. (1974). Mutants of Salmonella typhimurium defective in transport of branched-chain amino acids. Journal of Bacteriology 120, 10931101.

Kondo, E. \& MITSƯHASHI, S. (1964). Drug resistance of enteric bacteria. IV. Active transducing bacteriophage P1 CM produced by the combination of $\mathbf{R}$ factor with bacteriophage $\mathbf{P} 1$. Journal of Bacteriology 88, 1266-1276.

LaWrence, D. A., Smith, D. A. \& Rowbury, R. J. (1968). Regulation of methionine synthesis in Salmonella typhimurium: mutants resistant to inhibition by analogues of methionine. Genetics 58, 473-492.

LENNOX, E. S. (1955). Transduction of linked genetic characters of the host by bacteriophage P1. Virology 1, 190-206.

MojicA-A, T. (1975). Transduction by phage P1 CM clr-100 in Salmonella typhimurium. Molecular and General Genetics 138, 113-126.

Oeschger, N. S. \& Hartman, P. E. (1970). ICRinduced frameshift mutations in the histidine operon of Salmonella. Journal of Bacteriology 101, 490-504.

Ornellas, E. P. \& Stocker, B. A. D. (1974). Relation of lipopolysaccharide character to P1 sensitivity in Salmonella typhimurium. Virology $\mathbf{6 0}$, 491-502.

OSMUNDSEN, H. (1975). A computer programme for the determination of the kinetic constants of two enzymes acting simultaneously on the same substrate. Biochemical and Biophysical Research Communications 67, 324-330.

Payne, J. W. \& Gilvarg, C. (1971). Peptide transport. Advances in Enzymology 35, 187-244.

Rahmanian, M., Claus, D. R. \& Oxender, D. L. (1973). Multiplicity of leucine transport systems in Escherichia coli K-12. Journal of Bacteriology 116, 1258-1266.

ROSNER, J. L. (1972). Formation, induction and curing of bacteriophage P1 lysogens. Virology 48, 679-689.

Roth, J. R. (1970). Genetic techniques in studies of bacterial metabolism. Methods in Enzymology 17A, 3-35.

Sanderson, K. E. \& Hartman, P. E. (1978). Linkage map of Salmonella typhimurium, edition V. Microbiological Reviews 42, 471-519.

Smith, H. O. \& Levine, M. (1967). A phage P22 gene controlling integration of prophage. Virology 31, 207-216. 
Templeton, B. A. \& Savageau, M. A. (1974a). Wild, J., Walczak, W., KrajeWska-Grynkiewicz, Transport of biosynthetic intermediates: homo- K. \& KLopotowsKI, T. (1974). D-Amino acid serine and threonine uptake in Escherichia coli. dehydrogenase: the enzyme of the first step of Journal of Bacteriology 117, 1002-1009.

Templeton, B. A. \& Savageau, M. A. (1974b). Transport of biosynthetic intermediates: regulation of homoserine and threonine uptake in Escherichia coli. Journal of Bacteriology 120, 114 120. D-histidine and D-methionine racemization in Salmonella typhimurium. Molecular and General Genetics 128, 131-146.

Wood, J. M. (1975). Leucine transport in Escherichia coli. Journal of Biological Chemistry 250, 44774485 . 